\title{
Pemetaan dan Pengelompokan Karakteristik Usaha Pariwisata di Kota Manado Menggunakan Analisis Biplot
}

\author{
Tamariska Ega Tabitha Mandagi ${ }^{1)}$, Djoni Hatidja ${ }^{1 *}$, Mans Mananohas ${ }^{1)}$ \\ ${ }^{1)}$ Program Studi Matematika, Fakultas Matematika dan Ilmu Pengetahuan Alam \\ Universitas Sam Ratulangi Manado, Indonesia \\ ${ }^{*}$ Corresponding author: dhatidja@unsrat.ac.id
}

\begin{abstract}
ABSTRAK
Tujuan Penelitian ini, yaitu memetakan kelebihan dan kekurangan kecamatan-kecamatan di Kota Manado serta menggelompokan karakteristik usaha pariwisata yang ada di Kota Manado dengan menggunakan metode biplot. Data yang digunakan dalam penelitian ini adalah data sekunder yakni data jumlah usaha pariwisata tahun 2019 yang diperoleh dari Dinas Pariwisata dan Kebudayaan Kota Manado. Hasilnya menunjukkan bahwa objek dalam hal ini kecamatan-kecamatan yang dapat dikelompokkan memiliki karakteristik usaha pariwisata yang relatif sama adalah 1). Malalayang, Wanea, dan Sario 2). Bunaken, Singkil, Tuminting, Tikala, Paal Dua, dan Mapanget 3). Bunaken Kepulauan 4). Wenang. Kelompok pertama memiliki jumlah usaha pariwisata yang cukup pada hampir keseluruhan usaha pariwisata yang ada, tapi masih perlu diperhatikan untuk usaha pariwisata Kawasan Pariwisata, Penyediaan Akomodasi, dan Wisata Tirta. Kelompok kedua, merupakan kelompok kecamatan yang butuh banyak perhatian untuk dikembangkan lagi dikarenakan masih banyak kecamatan yang jumlah usaha pariwisatanya masih kurang bahkan tidak ada di kecamatan-kecamatan ini. Kelompok ketiga, kecamatan Bunaken Kepulauan memiliki jumlah usaha pariwisata yang paling unggul untuk usaha pariwisata Wisata Tirta, tapi untuk usaha pariwisata lainnya masih perlu dikembangkan lagi. Kelompok keempat, kecamatan Wenang memiliki jumlah usaha pariwisata yang unggul pada keseluruhan usaha pariwisata yang ada.
\end{abstract}

Kata kunci: Analisis biplot; pengelompokan; usaha pariwisata; Manado

\section{Mapping and Grouping the Characteristics of Tourism Enterprises in Manado City Using Biplot Analysis}

\begin{abstract}
The aims of this research was mapping the advantages and disadvantages of sub-districts in Manado City and grouping the characteristics of tourism enterprises in Manado City using the biplot analysis. The data used in this research are secondary data which is tourism enterprises data in 2019 that obtained from the Department of Tourism and Culture of Manado City. The results show that the object or sub-districts can be grouped having relatively similar tourism enterprises characteristics, are 1). Malalayang, Wanea, and Sario 2). Bunaken, Singkil, Tuminting, Tikala, Paal Dua, and Mapanget 3). Bunaken Kepulauan 4). Wenang. The first group has a sufficient number of tourism enterprises, but still needs to be considered for tourism businesses in the Tourism Area, Provision of Accommodation, and Water Tourism. The second group, is sub-district group that needs a lot of attention to be developed again. The third group, Bunaken Kepulauan has the most superior number for Water Tourism, but for other tourism enterprises it still needs to be developed further. The fourth group, Wenang has a number of tourism enterprises that excel in all existing tourism enterprises.
\end{abstract}

Keywords: Biplot analysis; grouping; tourism enterprises; Manado

(Article History： Received 06-07-2020; Accepted 05-11-2020; Published 28-04-2021)

\section{PENDAHULUAN}

Usaha pariwisata merupakan salah satu hal yang menjadi pokok perhatian pemerintah
Provinsi Sulawesi Utara terlebih khusus oleh pemerintah ibukota Provinsi Sulawesi Utara yaitu Kota Manado. Berlandaskan dari visi 
Rencana Pembangunan Jangka Panjang Daerah (RPJPD) Kota Manado 2005-2025 yaitu: "Manado Pariwisata Dunia", maka pariwisata di Kota Manado harus lebih giat dikembangkan lagi. Dalam upaya peningkatan dan pengembangan usaha pariwisata di daerah dalam hal ini Kota Manado, diperlukan kebijakan-kebijakan yang mungkin berbeda antar kecamatan, sesuai dengan kondisi usaha pariwisata yang ada di kecamatan masingmasing. Berdasarkan dengan jenis-jenis usaha pariwisata yang sudah ditetapkan pemerintah, akan dilihat bagaimana pemetaan posisi kecamatan-kecamatan yang ada di Kota Manado yang akan disesuaikan dengan usahausaha pariwisata yang ada di Kota Manado.

Purwanto et al. (2015), Gobel et al. (2013), Mamangkey et al. (2013), telah melaksanakan penelitian menggunakan analisis biplot tentang pemetaan SMA/SMK di kabupaten Minahasa Tenggara berdasarkan empat indikator standar nasional pendidikan, analisis karakteristik kualitas pengajar berdasarkan faktor mutu pelayanan di jurusan matematika FMIPA UNSRAT dan analisis pola pengeluaran rumah tangga di kabupaten Sangihe, Talaud dan Sitaro.

Kusuma et al. (2016) dan Barus et al. (2013) telah melaksanakan penelitian tentang aplikasi analisis korespondensi untuk melihat karakteristik usaha pariwisata di provinsi Bali. Srinadi et al. (2016) juga telah melaksanakan penelitian sebelumnya tentang analisis biplot terhadap pemetaan posisi dan karakteristik usaha pariwisata, namun objek yang digunakan adalah provinsi Bali.

Sejauh ini belum ditemukan penelitian tentang pemetaan posisi dan karakteristik usaha pariwisata di Kota Manado, Tujuan penelitian ini, yaitu memetakan dan menggelompokkan karakteristik usaha pariwisata di Kota Manado dengan menggunakan analisis biplot.

\section{METODE PENELITIAN}

Penelitian ini dilaksanakan di Laboratorium Statistika Jurusan Matematika FMIPA UNSRAT dan di tempat tinggal peneliti dan telah dilaksanakan pada bulan November 2019 sampai bulan April 2020. Data yang digunakan dalam penelitian adalah data sekunder yakni data jumlah usaha pariwisata tahun 2019 yang diperoleh dari Dinas Pariwisata dan Kebudayaan Kota
Manado. Objek penelitian adalah seluruh kecamatan yang ada di kota Manado yang disajikan pada Tabel 1.

Tabel 1. Kecamatan-Kecamatan yang Ada di Kota Manado

\begin{tabular}{|c|l|c|l|}
\hline No & \multicolumn{1}{|c|}{ Kecamatan } & No & \multicolumn{1}{|c|}{ Kecamatan } \\
\hline 1 & $\begin{array}{l}\text { Kecamatan Bunaken } \\
(B)\end{array}$ & 7 & $\begin{array}{l}\text { Kecamatan Singkil } \\
(\mathrm{Si})\end{array}$ \\
\hline 2 & $\begin{array}{l}\text { Kecamatan Bunaken } \\
\text { Kepulauan }(\mathrm{BK})\end{array}$ & 8 & $\begin{array}{l}\text { Kecamatan Tikala } \\
(\mathrm{Ti})\end{array}$ \\
\hline 3 & $\begin{array}{l}\text { Kecamatan Malalayang } \\
(\text { Mal })\end{array}$ & 9 & $\begin{array}{l}\text { Kecamatan } \\
\text { Tuminting }(\mathrm{Tu})\end{array}$ \\
\hline 4 & $\begin{array}{l}\text { Kecamatan Mapanget } \\
(\text { Map })\end{array}$ & 10 & $\begin{array}{l}\text { Kecamatan Wanea } \\
(\mathrm{Wa})\end{array}$ \\
\hline 5 & $\begin{array}{l}\text { Kecamatan Paal Dua } \\
(P D)\end{array}$ & 11 & $\begin{array}{l}\text { Kecamatan Wenang } \\
(\mathrm{We})\end{array}$ \\
\hline 6 & Kecamatan Sario $(\mathrm{Sa})$ & \multicolumn{3}{|c|}{ diamati adalah } \\
\hline
\end{tabular}

Peubah-peubah yang diamati adalah peubah usaha pariwisata berdasarkan undangundang RI Nomor 10 tahun 2009 tentang kepariwisataan yang disesuaikan dengan keadaan Kota Manado.

Metode analisis yang dilakukan dalam penelitian ini adalah sebagai berikut:

1. Data asal dianalisis dengan statistika deskriptif untuk mengetahui gambaran data secara umum menggunakan software pengolah angka. Dalam hal ini faktor usaha pariwisata adalah daya tarik wisata, jasa perjalanan wisata, jasa makanan dan minuman, penyediaan akomodasi, penyelenggaraan kegiatan hiburan dan rekreasi, penyelenggaraan pertemuan, perjalanan insentif, konferensi, dan pameran, wisata tirta dan spa.

2. Melakukan analisis biplot dengan langkahlangkah sebagai berikut:

- Pemasukan data (matriks data X)

- Penguraian matriks X yang telah distandarisasi dengan SVD

- Plot matriks $\mathrm{G}$ dan $\mathrm{H}$ secara tumpang tindih

\section{HASIL DAN PEMBAHASAN}

\section{Analisis Deskripsi}

Skor yang merupakan jumlah dari usaha-usaha pariwisata yang ada di kecamatan-kecamatan yang ada di Kota Manado disajikan dalam Tabel 2. 
Tabel 2. Skor Usaha Pariwisata di Kecamatan-Kecamatan di Kota Manado

\begin{tabular}{|l|l|l|l|l|l|l|l|l|l|}
\hline \multirow{2}{*}{ Kec } & \multicolumn{7}{|c|}{ Usaha Pariwisata } \\
\cline { 2 - 10 } & $X_{1}$ & $X_{2}$ & $X_{3}$ & $X_{4}$ & $X_{5}$ & $X_{6}$ & $X_{7}$ & $X_{8}$ & $X_{9}$ \\
\hline$B$ & 2 & 0 & 0 & 1 & 9 & 0 & 0 & 1 & 0 \\
\hline$B K$ & 0 & 4 & 0 & 1 & 37 & 0 & 0 & 24 & 0 \\
\hline Mal & 2 & 1 & 20 & 61 & 17 & 9 & 1 & 1 & 5 \\
\hline Map & 1 & 0 & 24 & 50 & 3 & 12 & 0 & 0 & 0 \\
\hline$P D$ & 2 & 0 & 15 & 21 & 1 & 7 & 1 & 0 & 0 \\
\hline$S a$ & 2 & 0 & 23 & 108 & 13 & 18 & 0 & 0 & 15 \\
\hline$S i$ & 1 & 0 & 4 & 7 & 5 & 1 & 0 & 0 & 0 \\
\hline$T i$ & 0 & 0 & 6 & 15 & 6 & 17 & 0 & 0 & 1 \\
\hline$T u$ & 1 & 0 & 6 & 28 & 3 & 0 & 0 & 1 & 0 \\
\hline$W a$ & 1 & 0 & 41 & 54 & 22 & 14 & 1 & 0 & 4 \\
\hline$W e$ & 12 & 4 & 51 & 214 & 41 & 35 & 6 & 0 & 13 \\
\hline
\end{tabular}

Dapat dilihat pada Tabel 2, skor/jumlah usaha pariwisata kecamatan Bunaken $(B)$ pada daya tarik wisata $\left(X_{1}\right)$ adalah 2 , artinya terdapat 2 daya tarik wisata $\left(X_{1}\right)$ pada kecamatan Bunaken. Untuk skor/jumlah usaha pariwisata kecamatan Bunaken $(B)$ pada Jasa Makanan dan Minuman $\left(X_{4}\right)$ adalah 1, Penyediaan Akomodasi $\left(X_{5}\right)$ adalah 9 dan Wisata Tirta $\left(X_{8}\right)$ adalah 1. Sedangkan untuk skor/jumlah usaha pariwisata kecamatan Bunaken $(B)$ pada Kawasan Pariwisata $\left(X_{2}\right)$, Jasa Perjalanan Wisata $\left(X_{3}\right)$, Penyelenggaraan Kegiatan Hiburan dan Rekreasi $\left(X_{6}\right)$, Penyelenggaraan Pertemuan, Perjalanan Insentif, Konferensi, dan Pameran $\left(X_{7}\right)$ dan SPA $\left(X_{9}\right)$ adalah 0 artinya tidak terdapat usaha-usaha pariwisata ini pada kecamatan Bunaken $(B)$. Penjelasan yang serupa untuk kecamatan-kecamatan lainnya.

\section{Analisis Biplot}

Menurut Mattjik et al. (2004), empat hal penting yang dapat dilihat pada biplot, yaitu:

1. Hubungan (korelasi) antar peubah, dengan menggunakan biplot peubah akan digambarkan sebagai garis berarah. Dua peubah yang memiliki korelasi positif tinggi akan digambarkan sebagai dua buah garis dengan arah yang sama, atau membentuk sudut yang sempit. Apabila dua peubah yang memiliki korelasi negatif tinggi akan digambarkan dalam bentuk dua garis yang arahnya berlawanan, atau membentuk sudut yang lebar (tumpul). Sedangkan dua buah peubah yang tidak berkorelasi akan digambarkan dalam bentuk dua garis yang mendekati $90^{\circ}$ (sikusiku).

2. Keragaman peubah, informasi ini digunakan untuk melihat apakah ada peubah tertentu yang nilainya hampir sama setiap objek ada yang sama besar dan ada juga yang sangat kecil. Dengan informasi ini, bisa diperkirakan pada peubah mana strategi tertentu harus ditingkatkan, serta sebaliknya. Dalam biplot, peubah dengan keragaman kecil digambarkan dengan vektor yang pendek, sedangkan peubah yang ragamnya besar digambarkan sebagai vektor yang panjang.

3. Kedekatan antar objek, informasi ini bisa dijadikan panduan objek mana yang memiliki kemiripan karakteristik dengan objek tertentu. Dalam biplot, dua objek dengan karakteristik sama akan digambarkan sebagai dua titik yang posisinya berdekatan.

4. Nilai peubah pada suatu objek, informasi ini digunakan untuk melihat keunggulan dari setiap objek. Objek yang terletak searah dengan arah dari suatu peubah dikatakan bahwa pada objek tersebut nilainya diatas rata-rata. Sebaliknya jika objek terletak berlawanan dengan arah dari peubah tersebut, maka objek tersebut memiliki nilai di bawah rata-rata. Objek yang hampir ada di tengah-tengah, memiliki nilai dekat dengan rata-rata.

Dalam percobaan multi-lingkungan (multienvironment trial) seperti pada industri pariwisata, seringkali sulit untuk mengetahui pola (pattern) interaksi perlakuan dengan lingkungan tanpa bantuan tampilan grafis dari data (Yan et al., 2001; Dehghani et al., 2006).

Analisis biplot diperoleh dengan penguraian nilai singular suatu matriks (Singular Value Decompotion, SVD). Suatu matriks $\mathrm{X}(\mathrm{nxp})$ yang berpangkat $\mathrm{r}$ dikoreksi terhadap nilai rataannya, maka matriks tersebut dapat dituliskan menjadi:

$X=U L A^{\prime}$

dengan matriks $U$ dan $A$ masing-masing

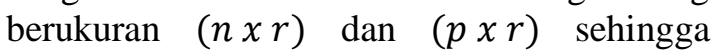
$U^{\prime} U=A^{\prime} A=\mathrm{I}$.

Menurut Jolliffe (1986), dengan menggunakan metode penguraian nilai singular matrik $\mathrm{X}$ akan diperoleh:

$$
\begin{aligned}
& \mathrm{X}^{\prime} \mathrm{X}=\left(\mathrm{GH}^{\prime}\right)^{\prime}\left(\mathrm{GH}^{\prime}\right)=\mathrm{HG}^{\prime} \mathrm{GH} \mathrm{H}^{\prime}=\mathrm{HU} \mathrm{UH}^{\prime} \\
& =\mathrm{HH}^{\prime}
\end{aligned}
$$




$$
\begin{aligned}
\mathrm{X}^{\prime} \mathrm{X} & =\left(\mathrm{GH}^{\prime}\right)\left(\mathrm{GH}^{\prime}\right)^{\prime}=\mathrm{GH}^{\prime} \mathrm{HG}^{\prime}=\mathrm{GA}^{\prime} \mathrm{AG} \mathrm{G}^{\prime} \\
& =\mathrm{GG}, \ldots \ldots \ldots \ldots \ldots \ldots \ldots \ldots \ldots \ldots \ldots \ldots \ldots \ldots
\end{aligned}
$$

Korelasi antara peubah ke- $j$ dan peubah ke- $k$ ditunjukkan oleh kosinus antara vektor $h_{j}$ dan $h_{k}$ serta jarak euclid antara $g_{h}$ dan $g_{i}$ akan sama dengan jarak euclid $x_{h}$ dan $x_{i}$

Plot antara 9 peubah usaha pariwisata (Daya tarik wisata, kawasan pariwisata, jasa perjalanan wisata, jasa makanan dan minuman, penyediaan akomodasi, penyelengaraan kegiatan hiburan dan rekreasi, penyelengaraan pertemuan, perjalanan insentif, konferensi, dan pameran, wisata tirta dan SPA) dan objek pengamatan (11 kecamatan di kota Manado) disajikan pada Gambar 1.

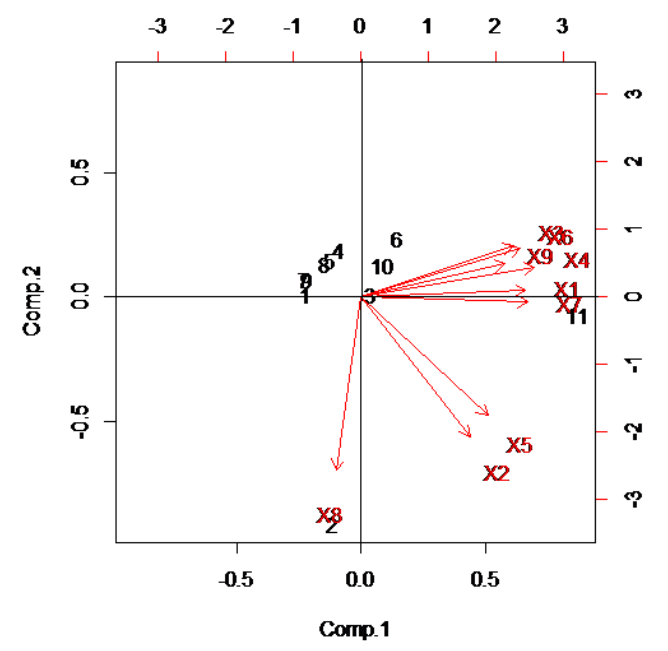

Gambar 1. Plot Antara 9 Peubah dan 11 Objek Pengamatan

Berdasarkan Gambar 1, dapat dijelaskan bahwa korelasi positif antar peubah terjadi pada peubah jasa perjalanan wisata $\left(X_{3}\right)$ dan peubah penyelengaraan kegiatan hiburan dan rekreasi $\left(X_{6}\right)$ karena kedua peubah tersebut memiliki arah yang sama dan sudut yang lancip. Hal ini berarti bahwa semakin bertambahnya jasa perjalanan wisata yang ada di kecamatan-kecamatan di kota Manado, semakin bertambah pula penyelengaraan kegiatan hiburan dan rekreasi yang ada di kecamatan-kecamatan di kota Manado, begitu pula sebaliknya. Selain itu, korelasi positif juga ditunjukkan oleh peubah jasa makanan dan minuman $\left(X_{4}\right)$ dan peubah SPA $\left(X_{9}\right)$, peubah daya tarik wisata $\left(X_{1}\right)$ dan penyelengaraan pertemuan, perjalanan insentif, konferensi, dan pameran $\left(X_{7}\right)$, juga peubah kawasan pariwisata $\left(X_{2}\right)$ dan peubah penyediaan akomodasi $\left(X_{5}\right)$.
Kedekatan antar objek dapat ditunjukkan oleh kecamatan Malalayang(3), Wanea(10), dan Sario(6) karena jarak ketiga objek terletak berdekatan. Hal ini menunjukan bahwa karakteristik ketiga objek tersebut relatif sama. Sama halnya dengan kecamatan Bunaken(1), Singkil(7), Tuminting(9), Tikala(8), Paal Dua(5), dan Mapanget(4) yang jarak objeknya juga berdekatan.

Keragaman yang besar terjadi pada peubah jasa makanan dan minuman $\left(X_{4}\right)$ karena memiliki vektor yang panjang. Hal ini menunjukkan bahwa kota Manado memiliki jasa makanan dan minuman yang sangat bervariasi di masing-masing kecamatannya. Adapun peubah lainnya yang juga memiliki keragaman besar adalah peubah kawasan pariwisata $\left(X_{2}\right)$, peubah penyediaan akomodasi $\left(X_{5}\right)$, dan peubah wisata tirta $\left(X_{8}\right)$.

Sedangkan keragaman kecil ada pada peubah SPA $\left(X_{9}\right)$, karena memiliki vektor yang paling pendek. Hal ini menunjukkan bahwa usaha pariwisata SPA yang ada di Kota Manado relatif sama antar kecamatankecamatan yang ada. Adapun peubah jasa perjalanan wisata $\left(X_{3}\right)$ juga mempunyai vektor yang pendek dibandingkan dengan vektor peubah yang lain.

Adapun objek-objek yang memiliki keunggulan terhadap peubah dapat dilihat pada kecamatan Bunaken Kepulauan(2) yang memiliki usaha pariwisata paling dominan dalam hal wisata tirta $\left(X_{8}\right)$, karena vektor dari peubah tersebut searah dengan kecamatan Bunaken Kepulauan(2). Selain itu juga dapat dilihat bahwa, kecamatan Wenang(11) memiliki usaha pariwisata paling dominan dalam hal penyelengaraan pertemuan, perjalanan insentif, konferensi, dan pameran $\left(X_{7}\right)$.

Dari gambar 1 di atas juga dapat dilihat terjadi pengelompokkan baik antar objek maupun antar peubah. Untuk pengelompokan objek dapat dilihat ada 4 kelompok objek yang terbentuk yaitu kelompok Malalayang(3), Wanea(10), dan Sario(6), kelompok Bunaken(1), Singkil(7), Tuminting(9), Tikala(8), Paal Dua(5), dan Mapanget(4), kelompok Bunaken Kepulauan(2) dan kelompok Wenang(11). Untuk pengelompokkan peubah dapat dilihat ada 3 kelompok peubah yang terbentuk yaitu kelompok peubah jasa perjalanan wisata $\left(X_{3}\right)$, peubah penyelengaraan kegiatan hiburan dan rekreasi $\left(X_{6}\right)$, peubah jasa makanan dan 
minuman $\left(X_{4}\right)$, peubah SPA $\left(X_{9}\right)$, peubah daya tarik wisata $\left(X_{1}\right)$ dan peubah penyelengaraan pertemuan, perjalanan insentif, konferensi, dan pameran $\left(X_{7}\right)$, kelompok peubah kawasan pariwisata $\left(X_{2}\right)$ dan peubah penyediaan akomodasi $\left(X_{5}\right)$, dan kelompok peubah Wisata Tirta $\left(X_{8}\right)$. Kelompok objek yang pertama, kelompok Malalayang(3), Wanea(10), dan Sario(6) terletak hampir ditengah kelompok peubah peubah jasa perjalanan wisata $\left(X_{3}\right)$, peubah penyelengaraan kegiatan hiburan dan rekreasi $\left(X_{6}\right)$. peubah jasa makanan dan minuman $\left(X_{4}\right)$, peubah SPA $\left(X_{9}\right)$, peubah daya tarik wisata $\left(X_{1}\right)$ dan peubah penyelengaraan pertemuan, perjalanan insentif, konferensi, dan pameran $\left(X_{7}\right)$, artinya kelompok objek Malalayang(3), Wanea(10), dan Sario(6) memiliki nilai yang mendekati rata-rata pada kelompok peubah tersebut. Kelompok objek yang kedua, kelompok Bunaken(1), Singkil(7), Tuminting(9), Tikala(8), Paal Dua(5), dan Mapanget(4), terletak berlawanan arah dari semua vektor peubah yang ada, artinya kelompok Bunaken(1), Singkil(7), Tuminting(9), Tikala(8), Paal Dua(5), dan Mapanget(4) memiliki nilai hampir di bawah rata-rata dari keseluruhan peubah yang ada. Kelompok objek yang ketiga, kelompok Bunaken Kepulauan(2), terletak searah dengan kelompok peubah Wisata Tirta $\left(X_{8}\right)$, artinya kelompok Bunaken Kepulauan(2) memiliki nilai di atas rata-rata untuk kelompok peubah Wisata Tirta $\left(X_{8}\right)$, tapi nilainya untuk kelompok peubah lainnya jauh di bawah dari nilai rata-rata. Kelompok objek keempat, kelompok Wenang(11) terletak searah dengan kelompok peubah peubah jasa perjalanan wisata $\left(X_{3}\right)$, peubah penyelengaraan kegiatan hiburan dan rekreasi $\left(X_{6}\right)$. peubah jasa makanan dan minuman $\left(X_{4}\right)$, peubah SPA $\left(X_{9}\right)$, peubah daya tarik wisata $\left(X_{1}\right)$ dan peubah penyelengaraan pertemuan, perjalanan insentif, konferensi, dan pameran $\left(X_{7}\right)$ dan kelompok peubah kawasan pariwisata $\left(X_{2}\right)$ dan peubah penyediaan akomodasi $\left(X_{5}\right)$, yang artinya kelompok Wenang(11) memiliki nilai di atas rata-rata dari peubah-peubah tersebut.

Keakuratan biplot dalam menerangkan tingkat keragaman dari matriks data asal dirumuskan sebagai berikut (Everit, 1978):

$\rho^{2}=\frac{\left(\lambda_{1}+\lambda_{2}\right)}{\sum_{k=1}^{p} \lambda_{k}}$ dimana, $\lambda_{1}=$ akar ciri terbesar pertama; $\lambda_{2}=$ akar ciri terbesar kedua; $\lambda_{k}=$ akar ciri terbesar ke-k; $\rho^{2}=$ tingkat keakuratan.

Berdasarkan analisis biplot, diperoleh akar ciri terbesar pertama $\lambda_{1}=4.356407 \mathrm{e}+03$ dan akar ciri terbesar kedua $\lambda_{2}=1.733897 \mathrm{e}+02$. Dari persamaan (4), diperoleh nilai $\rho^{2}=0,9751 \quad(97,51$. Hal ini berarti bahwa keragaman yang dapat diterangkan biplot adalah sebesar $97.51 \%$ dari keragaman data yang sebenarnya. Ini menunjukkan bahwa interpretasi biplot yang dihasilkan mampu menerangkan dengan baik hubungan antara peubah usaha pariwisata dan kecamatan-kecamatan di Kota Manado.

\section{KESIMPULAN}

Terdapat 4 kelompok kecamatan dan 3 kelompok usaha pariwisata yang terbentuk. Kelompok kecamatan yang pertama, kelompok Malalayang, Wanea, dan Sario memiliki jumlah usaha pariwisata yang cukup pada hampir keseluruhan usaha pariwisata yang ada. Tapi masih perlu diperhatikan untuk usaha pariwisata Kawasan Pariwisata, Penyediaan Akomodasi, dan Wisata Tirta. Kelompok kecamatan yang kedua, kelompok Bunaken, Singkil, Tuminting, Tikala, Paal Dua, dan Mapanget, merupakan kelompok kecamatan yang butuh banyak perhatian untuk dikembangkan lagi dikarenakan masih banyak kecamatan yang jumlah usaha pariwisatanya masih kurang bahkan tidak ada di kecamatankecamatan ini. Kelompok kecamatan yang ketiga, kecamatan Bunaken Kepulauan memiliki jumlah usaha pariwisata yang paling unggul untuk usaha pariwisata Wisata Tirta, tapi untuk kelompok usaha pariwisata lainnya masih perlu dikembangkan lagi. Kelompok kecamatan yang keempat, kecamatan Wenang memiliki jumlah usaha pariwisata yang unggul pada keseluruhan usaha pariwisata yang ada.

\section{DAFTAR PUSTAKA}

Barus, N.S., Kencana, I.P. \& Sukarsa K.G. 2013. Pengelompokkan kabupaten di provinsi bali berdasarkan perkembangan fasilitas pariwisata. Jurnal Matematika, 2: 53-58. 
Dehghani, H., Ebadi, A. \& Yousefi, A. 2006. Biplot analysis of genotype by environment interaction for barley yield in Iran. Agronomy Journal, 98: 388393.

Everit, B. 1978. Graphical Techniques for Multivariate Data. Heinermann Educational Books.

Gobel, T.V., Hatidja, D. \& Komalig, H. 2013. Karakteristik Kualitas Pengajar Berdasarkan Faktor Mutu Pelayanan di Jurusan Matematika FMIPA UNSRAT, Jurnal MIPA UNSRAT Online, 2(1): 29-33.

Jolliffe I.T. 2002. Principal Component Analysis, Second Edition”, Encyclopedia of Statistics in Behavioral Science. Springer-Verlag, New York.

Kusuma, A., Srinadi, I.G.A.M. \& Sari, K. 2016. Aplikasi Analisis Korespondensi untuk Melihat Karakteristik Usaha Pariwisata di Provinsi Bali, E-Jurnal Matematika, 5(1): 76-81.

Mamangkey, A., Prang. J.D. \& Hatidja D. 2013. Pola Pengeluaran Rumah Tangga di Kabupaten Sangihe, Talaud dan Sitaro Menggunakan Analisis Biplot, Jurnal MIPA UNSRAT Online, 2(1): 34-39.
Mattjik, A.A., Sumertajaya, M., Wijayanto, H., Indahwati, A.K. \& Sartono, B. 2004. Modul Teori Pelatihan Analisis Multivariat., Departemen Statistika FMIPA IPB Bogor.

Purwanto, C., Hatidja, D. \& Paendong, M. 2015. Pemetaan SMA/SMK di Kabupaten Minahasa Tenggara Berdasarkan Empat Indikator Standar Nasional Pendidikan Dengan Menggunakan Analisis Biplot. Jurnal De Cartesian, 4(1): 34-41.

Srinadi, I.G.A.M. \& Sumarjaya, I.W. 2016. Analisis Biplot untuk Pemetaan Posisi dan Karakteristik Usaha Pariwisata di Provinsi Bali. Jurnal Matematika, 6: 34-45.

Undang-Undang Republik Indonesia Nomor 10 Tahun 2009 Tentang Kepariwisataan.

Yan, W. 2001. GGEbiplot - A windows application for graphical analysis of multienvironment trial data and other types of two-way data. Agronomy Journal, 93: 1111-1118. 